\title{
AGRONOMIC AND QUALITATIVE PERFORMANCE OF DENSELY CULTIVATED ONION CULTIVARS AS AFFECTED BY POTASSIUM FERTILISATION ${ }^{1}$
}

\author{
FRANCISCO DAS CHAGAS GONÇALVES ${ }^{2}$, LEILSON COSTA GRANGEIRO ${ }^{2}$, VALDÍVIA DE FÁTIMA LIMA DE \\ SOUSA $^{2}$, PRISCILA MAYLANA MODESTO DE JESUS ${ }^{2}$, GERLANI ALVES DA SILVA ${ }^{2}$
}

\begin{abstract}
The increase in plant density, combined with the use of hybrids in onion cultivation, has provided significant gains in yield, with a direct impact on the amount of absorbed macronutrients. The present work aimed to evaluate the yield and quality of two onion cultivars under a densified system as a function of potassium doses supplied via fertirrigation. A randomized complete block design was used in a $2 \times 7$ factorial scheme with four replications. The treatments consisted of two cultivars (IPA 11 and Rio das Antas) and seven potassium doses $\left(0,70,140,210,280,350\right.$ and $\left.420 \mathrm{~kg} \mathrm{ha}^{-1} \mathrm{~K}_{2} \mathrm{O}\right)$, provided by fertigation. The potassium doses that provided maximum total and commercial yields were 215 and $216 \mathrm{~kg} \mathrm{ha}^{-1}$ of $\mathrm{K}_{2} \mathrm{O}$, respectively. The soluble solids and the percentage of bulbs of classes 2, 3 and 4 were not influenced by potassium fertilization. There was a reduction in the percentage of non-commercial bulbs with the increase of potassium doses. The dose with maximum economical efficiency was $210.6 \mathrm{~kg} \mathrm{ha}^{-1}$ of $\mathrm{K}_{2} \mathrm{O}$, responsible for a commercial yield of $61.8 \mathrm{tha}^{-1}$.
\end{abstract}

Keywords: Allium cepa. Plant nutrition. Yield.

\section{DESEMPENHO AGRONÔMICO E QUALITATIVO DE CULTIVARES DE CEBOLA ADENSADAS EM FUNÇÃO DA ADUBAÇÃO POTÁSSICA}

RESUMO - O aumento na densidade de plantas aliado à utilização de híbridos no cultivo da cebola tem proporcionado ganhos significativos na produtividade desta cultura, com impacto direto na quantidade de macronutrientes absorvidos. Objetivou-se avaliar a produtividade e qualidade de duas cultivares de cebola sob sistema adensado em função de doses de potássio fornecidas via fertirrigação em Mossoró/RN. Adotou-se o delineamento em blocos casualizados, em esquema fatorial 2 × 7, com quatro repetições. Os tratamentos constituíram-se de duas cultivares (IPA 11 e Rio das Antas) e sete doses de potássio (0, 70, 140, 210, 280,350 e $420 \mathrm{~kg} \mathrm{ha}^{-1}$ de $\mathrm{K}_{2} \mathrm{O}$ ), fornecidas via fertirrigação. As doses de potássio que proporcionaram as máximas produtividades total e comercial de bulbos foram de 215 e $216 \mathrm{~kg} \mathrm{ha}^{-1}$ de $\mathrm{K}_{2} \mathrm{O}$, respectivamente. Os sólidos solúveis e o percentual de bulbos das classes 2, 3 e 4 não foram influenciados pela adubação potássica. Houve redução do percentual de bulbos não comerciais com o aumento das doses de potássio. A dose de máxima eficiência econômica foi de $210,6 \mathrm{~kg} \mathrm{ha}^{-1} \mathrm{de}_{2} \mathrm{O}$, responsável por uma produtividade comercial de $61,8 \mathrm{tha}^{-1}$.

Palavras-chave: Allium cepa. Nutrição de plantas. Rendimento.

\footnotetext{
"Corresponding author

${ }^{1}$ Received for publication in $01 / 24 / 2019$; accepted in $07 / 22 / 2019$.

Paper extracted from the doctoral thesis of the fisrt author.

${ }^{2}$ Department of Agronomic and Forestry Sciences, Universidade Federal Rural do Semi-Árido, Mossoró, RN, Brazil; francisco.goncalves@ufersa.edu.br _ ORCID: 0000-0002-0730-9647, leilson@ufersa.edu.br - ORCID: 0000-0002-4613-3605, valdivia_sousa@hotmail.com - ORCID: 0000-0002-5377-6844, priscilamodesto@ymail.com - ORCID: 0000-0002-3144-1832, gerlani_alves@hotmail.com - ORCID: 0000-0003-0894-4025.
} 


\section{INTRODUCTION}

The yield and quality of onion bulbs are associated with genetic, climatic and phytotechnical factors. Increased plant density, combined with the use of hybrids in onion cultivation, has promoted significant gains in the yield of this crop, with direct impact on the quantity of macronutrients absorbed.

Regardless of the soil class in which it is cultivated, potassium $(\mathrm{K})$ is the nutrient extracted in greatest quantity by the onion plant (VIDIGAL et al. 2010; MORAES et al. 2016; BACKES et al. 2018). The increments promoted by this nutrient are due to the range of functions performed, such as participation in the activation of various enzymes, vital role in the synthesis of carbohydrates and proteins, improvement in the water regime of plants and, consequently, increase in their tolerance to drought, frost and salinity (MAATHUIS, 2009).

Studies with $\mathrm{K}$ fertilisation in onion have demonstrated yields from 2.9 to $32.0 \%$ with the $\mathrm{K}_{2} \mathrm{O}$ dose of $100 \mathrm{~kg} \mathrm{ha}^{-1}$ (NABI et al. 2010; KAUR et al. 2017), from 36.1 to $85.8 \%$ with the $\mathrm{K}_{2} \mathrm{O}$ dose of 120 $\mathrm{kg} \mathrm{ha}^{-1}$ (SAUD et al. 2013), from 9.4 to $23.4 \%$ with the $\mathrm{K}_{2} \mathrm{O}$ dose of $180 \mathrm{~kg} \mathrm{ha}^{-1}$ (MARROCOS et al. 2018 ) and $78.2 \%$ with the $\mathrm{K}_{2} \mathrm{O}$ dose of $225 \mathrm{~kg} \mathrm{ha}^{-1}$ (CECÍLIO FILHO et al. 2010). The observed variations are due to the genetic material, $\mathrm{K}$ levels in soil, the forms and moment of nutrient application, besides plant density.

In this context, this study aimed to evaluate whether the yield and quality of two onion cultivars under a dense planting system improved as a function of $\mathrm{K}$ doses supplied through fertigation.

\section{MATERIAL AND METHODS}

The experiment was carried out from August to December 2015, at the Rafael Fernandes Experimental Farm, belonging to the Federal Rural University of the Semi-Arid Region (UFERSA) and located in the rural area of the municipality of Mossoró, at the coordinates $5^{\circ} 03^{\prime} 3^{\prime \prime} \mathrm{S}$ and $37^{\circ} 23^{\prime} 5^{\prime \prime}$ $\mathrm{W}$ and $72 \mathrm{~m}$ altitude (LUCENNA et al. 2011). During the experiment, the average temperature was $27.2{ }^{\circ} \mathrm{C}$, and the mean relative humidity was $64.5 \%$.

The soil was classified as Argissolo Vermelho Distrófico Típico (Ultisol) (RÊGO et al. 2016). Soil analysis in the $0-0.2 \mathrm{~m}$ layer revealed $\mathrm{pH}$ in $\mathrm{H}_{2} \mathrm{O}$ of 6.4; electrical conductivity (EC) of $0.05 \mathrm{dS} \mathrm{m}^{-1}$; $\mathrm{P}_{\text {Mehlich1 }}$ of $4.74 \mathrm{mg} \mathrm{dm}^{-3}$; $\mathrm{K}$ of $77.4 \mathrm{mg} \mathrm{dm}^{-3}$; $\mathrm{Ca}, \mathrm{Mg}$, and $\mathrm{H}+\mathrm{Al}$ contents and effective cation exchange capacity (CEC) of 2.0, 0.8, 0.0 and $4.2 \mathrm{cmol}_{\mathrm{c}} \mathrm{dm}^{-3}$, respectively. Sand, silt and clay contents were, respectively, 820,40 and $140 \mathrm{~g} \mathrm{~kg}^{-1}$.

The experimental design was randomised complete blocks in a $2 \times 7$ factorial scheme with four replicates. Treatments consisted of the combination of two onion cultivars ('Rio das Antas' and 'IPA $11^{\prime}$ ') and seven doses of $\mathrm{K}(0,70,140,210,280,350$ and $420 \mathrm{~kg} \mathrm{ha}^{-1}$ of $\mathrm{K}_{2} \mathrm{O}$ ). Each plot consisted of 3.0 $\mathrm{m}$ of bed with a width of $1.0 \mathrm{~m}$, containing eight rows of plants, spaced by $0.10 \times 0.06 \mathrm{~m}$. The six central rows were considered as usable area, disregarding two plants on each end.

The area used had been recently deforested (with no history of previous crops), and soil preparation consisted of plowing, harrowing and building of beds. Fertilisation at planting was performed based on soil analysis and the recommendation of Cavalcante (2008), using $150 \mathrm{~kg}$ $\mathrm{ha}^{-1}$ of $\mathrm{P}_{2} \mathrm{O}_{5}$ in the form of triple superphosphate.

Irrigation was applied by a drip system, with three hoses per bed, spaced by $0.30 \mathrm{~m}$, and drippers with an average flow rate of $1.5 \mathrm{~L} \mathrm{~h}^{-1}$, spaced by 0.30 $\mathrm{m}$. Irrigations were performed daily, and the water depths were determined based on crop evapotranspiration (ALLEN et al. 1998), applying a total water depth of $860.8 \mathrm{~mm} \mathrm{ha}^{-1}$.

The water used in irrigation came from a deep tubular well of the Arenito Açu aquifer, with the following characteristics: $\mathrm{pH} 7.3$; EC of $0.59 \mathrm{dS} \mathrm{m}^{-1}$; $0.50,1.95,2.60,1.10,3.20,0.0$ and $4.10 \mathrm{mmol}_{\mathrm{c}} \mathrm{L}^{-1}$ of $\mathrm{K}^{+}, \mathrm{Na}^{+}, \mathrm{Ca}^{2+}, \mathrm{Mg}^{2+}, \mathrm{Cl}^{-}, \mathrm{CO}_{3}{ }^{2-}$ and $\mathrm{HCO}_{3}{ }^{-}$; and sodium adsorption ratio (SAR) of $1.4 \mathrm{mg} \mathrm{L}^{-1}$, respectively.

In order to guarantee the final plant stand, sowing was performed manually, placing 3 to 4 seeds per hole at $2.0 \mathrm{~cm}$ depth, spaced by $0.10 \times 0.06$ $\mathrm{m}$. Weeds were controlled by hand, in a total of two weedings, the first at 8 days after sowing (DAS) and the second, 12 days after the first, when thinning was also performed, leaving only one plant per hole.

Top-dressing fertilisation was performed weekly through fertigation, split into nine applications, starting at $28 \mathrm{DAS}$ and ending at 84 DAS, supplying, respectively, 179.88, 139.4, 13.70 and $48.50 \mathrm{~kg} \mathrm{ha}^{-1}$ of $\mathrm{N}, \mathrm{P}_{2} \mathrm{O}_{5}, \mathrm{Mg}$ and $\mathrm{Ca}$, while $\mathrm{K}$ was applied according to the doses of each treatment. The sources used were urea, $\mathrm{KCl}$, monoammonium phosphate, $\mathrm{MgSO}_{4}, \mathrm{Ca}\left(\mathrm{NO}_{3}\right)_{2}$ and $\mathrm{KNO}_{3}$.

When about $70 \%$ of the plants were lodged, at 99 DAS, irrigation was suspended, and the curing process began. After 23 days of irrigation suspension, the plants were harvested.

The following characteristics were evaluated: $\mathrm{K}$ content in the diagnostic leaf (KDL), the total yield of bulbs (TY), the marketable yield of bulbs (MY), non-marketable yield (NMY), classification of bulbs (marketable and non-marketable), percentage of non-marketable bulbs (PNMB), total soluble solids (SS), titratable acidity (TA), SS/TA ratio and pungency (PUNG).

For KDL $\left(\mathrm{g} \mathrm{kg}^{-1}\right)$, the highest leaves of all plants of the usable area of the plot were collected at 62 DAS, washed, dried in a forced ventilation oven at $65^{\circ} \mathrm{C}$ and ground, and $\mathrm{K}$ content was determined by flame emission photometry. The TY $\left(\mathrm{t} \mathrm{ha}^{-1}\right)$ was 
obtained by the sum of MY and NMY. The MY $\left(\mathrm{t} \mathrm{ha} \mathrm{a}^{-1}\right)$ was determined by the total weight of bulbs with a diameter $>35 \mathrm{~mm}$, without defects. Bulb classification (\%) for marketable bulbs was based on the cross-sectional diameter of the bulb, which, according to the norms of the Ministry of Agriculture, Livestock and Food Supply (BRASIL 1995) can be classified as follows: Class 2 (35-49 $\mathrm{mm})$, Class 3 (50-74 $\mathrm{mm})$, Class $4(75-90 \mathrm{~mm})$ and Class 5 (> $90 \mathrm{~mm})$. Non-marketable bulbs (\%) included those of Class $1(<35 \mathrm{~mm})$, double and defective bulbs. The SS ( ${ }^{\circ}$ Brix) was determined by sampling four bulbs per usable plot, crushing them in a food processor for juice extraction, and then the digital refractometer readings were taken for each sample. The TA $\left(\mathrm{mEq} \mathrm{H}_{3} \mathrm{O}^{+} 100 \mathrm{~g}^{-1}\right)$ was determined using a $20 \mathrm{~mL}$ aliquot of the juice extracted from the bulbs, mixed with three drops of $1 \%$ phenolphthalein, followed by titration to the endpoint with $\mathrm{NaOH}$ solution $(0.1 \mathrm{~N})$, previously standardised. The SS/TA ratio was determined by dividing the values of SS ( ${ }^{\circ}$ Brix) by TA $\left(\mathrm{mEq} \mathrm{H}_{3} \mathrm{O}^{+}\right.$ $\left.100 \mathrm{~g}^{-1}\right)$. The PUNG $\left(\mu \mathrm{mol} \mathrm{g}^{-1}\right)$ was determined using a $0.5 \mathrm{~mL}$ aliquot of the juice extracted from the bulbs and quantifying pyruvic acid by adopting the method described by Melo et al. (2012).

Based on the fitting of the equations, the $\mathrm{K}$ doses that led to maximum technical efficiency (MTE) and maximum economic efficiency (MEE) were calculated. The MEE dose was calculated based on the first derivative of the regression equations, which is equal to the exchange ratio $\left(\mathrm{K}_{2} \mathrm{O} \mathrm{kg}\right.$ price divided by the onion bulb $\mathrm{kg}$ price), according to
Resende et al. (2016). In this study, the values used for the variables of per kilogram of marketable bulb and kilogram of $\mathrm{K}\left(\right.$ as $\left.\mathrm{K}_{2} \mathrm{O}\right)$ were $\mathrm{R} \$ 1.25$ and $\mathrm{R} \$ 3.20$, respectively.

$$
x^{\prime}=\left[a_{1}-(\text { exchange ratio })\right] /\left[2 *\left(-a_{2}\right)\right]
$$

Where:

$x$ - represents the economic dose $\left(\mathrm{kg} \mathrm{ha}^{-1}\right)$;

$a_{1}$ - represents the production increment rate;

$a_{2}-$ represents the point of maximum production.

The data were subjected to analysis of variance and, when there was a significant effect for the qualitative factor (cultivars), the means were compared by the $\mathrm{F}$ test at 5\% probability level. Regression analysis was carried out for the quantitative factor (doses), using the program Sisvar version 5.6 (FERREIRA, 2011).

\section{RESULTS AND DISCUSSION}

The interaction between the factors cultivars and $\mathrm{K}$ doses was not significant for the evaluated characteristics, except for TA and the SS/TA ratio. The evaluated characteristics were influenced by the cultivars, while the effect of doses was significant for KDL, TY, MY, PNMB, TA, the SS/TA ratio and PUNG.

The means of KDL as a function of $\mathrm{K}$ doses did not fit any mathematical model. KDL varied from 20.88 to $28.17 \mathrm{~g} \mathrm{~kg}^{-1}$. The cultivar 'IPA 11 ' had a higher KDL compared with 'Rio das Antas' (Table 1).

Table 1. Summary of the analysis of variance for potassium content in the diagnostic leaf (KDL), total yield (TY), marketable yield (MY), non-marketable yield (NMY), percentage of bulbs in the classes 2 (PB2), 3 (PB3) and 4 (PB4) and percentage of non-marketable bulbs (PNMB) of onion as a function of potassium (K) doses and cultivars.

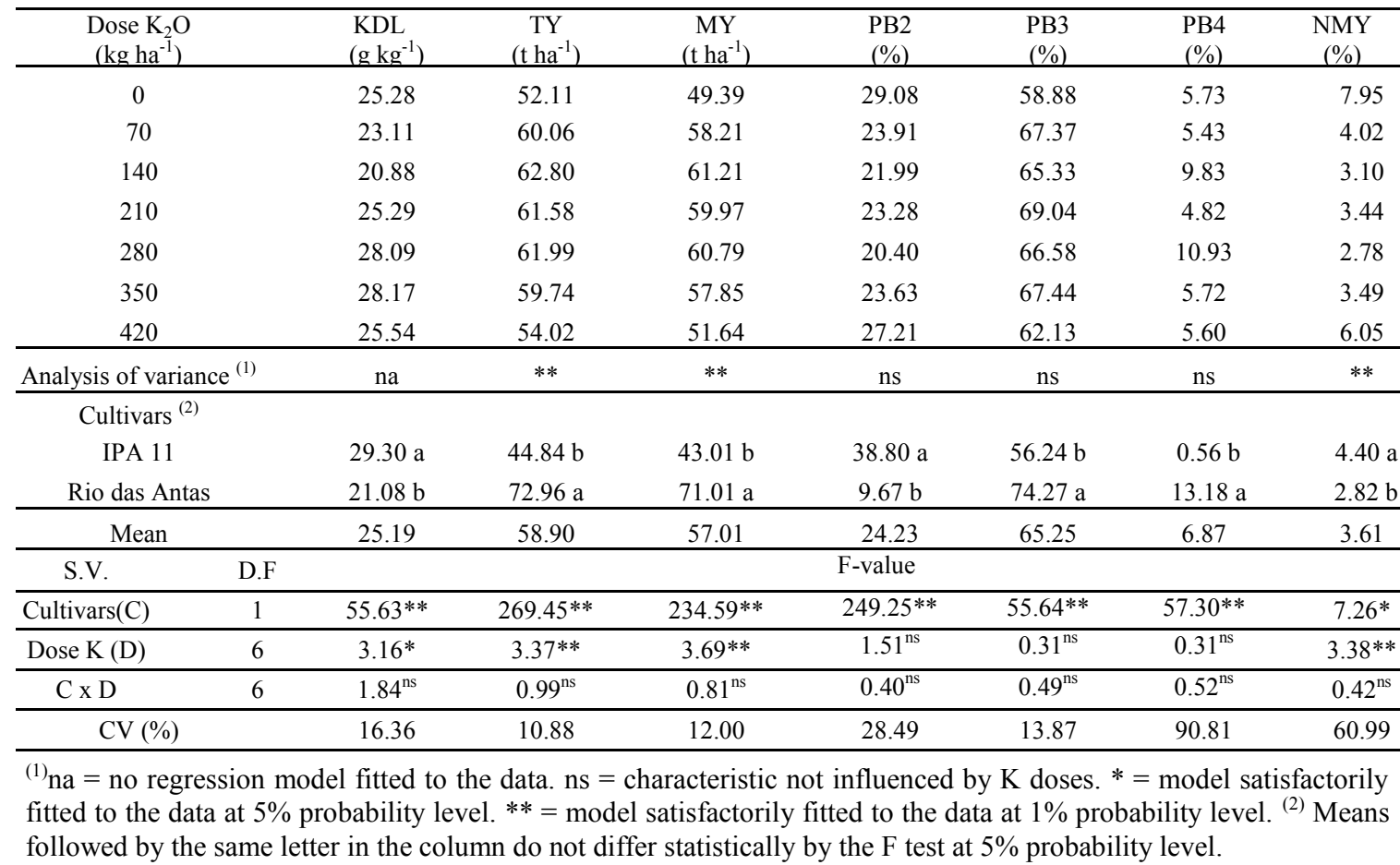

Rev. Caatinga, Mossoró, v. 32, n. 4, p. 889 - 896, out. - dez., 2019 
The KDL values found were lower than those described by Trani et al. (2014) as adequate for onion (30 to $50 \mathrm{~g} \mathrm{~kg}^{-1}$ ). However, no symptoms of $\mathrm{K}$ deficiency were observed, even in the treatment without the addition of this nutrient. A positive response to $\mathrm{K}$ fertilisation, but with leaf contents of this nutrient superior to those obtained in this experiment, was verified by Marrocos et al. (2018), who evaluated the effect of cultivation periods and $\mathrm{K}$ doses on the cultivar 'IPA 11', obtaining average leaf $\mathrm{K}$ contents of 51.22 and $43.84 \mathrm{~g} \mathrm{~kg}^{-1}$ in September/2012 and April/2013, respectively.

An explanation for this difference may be related to the interaction in the soil between $\mathrm{K}$ and the elements $\mathrm{Ca}$ and $\mathrm{Mg}$ since in the soil (Argissolo
Vermelho Amarelo - Ultisol) used by Marrocos et al. (2018), this ratio was 6.4, whereas, in the present study, it was 14.0. The effect of the $(\mathrm{Ca}+\mathrm{Mg}) / \mathrm{K}$ ratio on the absorption of these three elements in the vegetative part of the garlic crop was observed by Bull et al. (1998), who found that that the reduction in this ratio from 207.3 to 1.9 practically quadrupled the leaf $\mathrm{K}$ content. The reduction in $\mathrm{K}$ absorption is related to the antagonistic effect between $\mathrm{K}$ and $\mathrm{Mg}$ due to competition for ligand compounds in plant metabolism (FAGERIA, 2001).

The average TY values as a function of $K$ doses significantly fitted to the quadratic regression model (Figure 1).

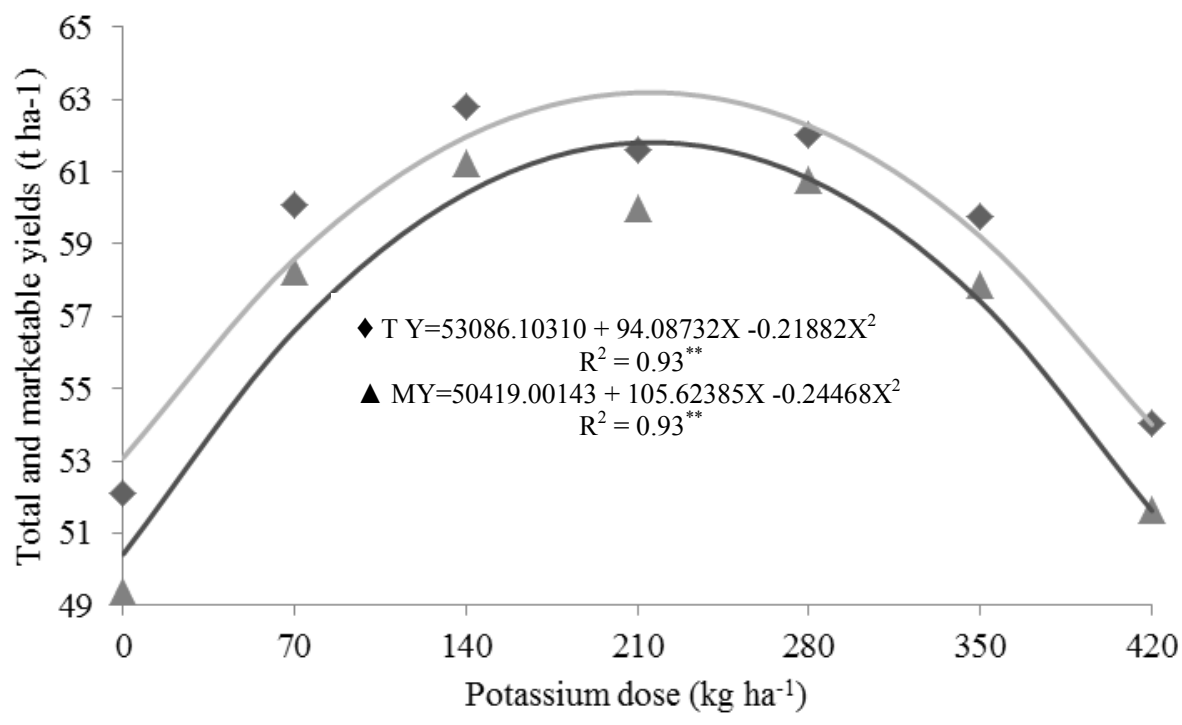

Figure 1. Total and marketable yields of onion bulbs as a function of potassium doses.

The $\mathrm{K}_{2} \mathrm{O}$ dose that maximised $\mathrm{TY}$ $\left(63.20 \mathrm{t} \mathrm{ha}^{-1}\right)$ was $215 \mathrm{~kg} \mathrm{ha}^{-1}$, with a $21.3 \%$ increment compared with the treatment without application. Among the cultivars, the TY of 'Rio das Antas' was on average $63 \%$ higher than that of 'IPA 11'. Positive results of $\mathrm{K}$ fertilisation on the TY of onion have also been observed by Saud et al. (2013), Poornima et al. (2016) and Aftab et al. (2017).

The estimated TY of the control was $53.09 \mathrm{t}$ $\mathrm{ha}^{-1}$, considered high in comparison to the average Brazilian yield in the year 2016 (28.34 $\left.\mathrm{t} \mathrm{ha}^{-1}\right)$. Defined as medium by Cavalcante (2008), the K content in soil $\left(77 \mathrm{mg} \mathrm{dm}^{-3}\right)$ associated with the amount of this nutrient added through irrigation water $\left(203.23 \mathrm{~kg} \mathrm{ha}^{-1}\right.$ of $\left.\mathrm{K}_{2} \mathrm{O}\right)$, contributed to this result.

A quadratic regression model fitted to the mean values of MY, similarly to TY (Figure 1). The $\mathrm{K}_{2} \mathrm{O}$ dose that maximised MY $\left(61.81 \mathrm{tha}^{-1}\right)$ was 216 $\mathrm{kg} \mathrm{ha}{ }^{-1}$. Relative to the treatment without $\mathrm{K}$ application, the increment was approximately $23 \%$. The reduction of yield observed with doses higher than those that maximised TY and MY might be related to both, the effect of competition between $\mathrm{K}$ with $\mathrm{Ca}$ and $\mathrm{Mg}$ (FAGERIA, 2001) and to the saline effect due to excess $\mathrm{K}$ in the cell vacuole. In order to compensate for the increase of ionic concentration in the vacuole, the plant accumulates solutes in the cytosol (e.g., proline, sorbitol and glycine betaine), derivatives of active metabolic process, hence, using carbon in large quantities, resulting in reduced crop yield (TAIZ et al. 2017).

A higher proportion of Class 3 bulbs (PB3) was produced by cultivar 'Rio das Antas' (74.27\%) than 'IPA 11' (56.24\%), whereas the percentage of bulbs in Class 2 (PB2) was four times higher in 'IPA 11'. The percentage of bulbs in Class 4 (PB4) was $13.17 \%$ for 'Rio das Antas' and only $0.55 \%$ for 'IPA 11 '. Bulb size is highly correlated with the average mass, which is characterised by a high impact of the inheritance of dominant genes, wherein crosses can result in hybrids with a more uniform production and with larger bulbs, due to the gain obtained by heterosis (PAVLOVIC et al. 2017).

The results found corroborate those observed by Faria et al. (2012), who evaluated the agronomic performance of 19 hybrids and 50 strains of onion and found that hybrids were not only more 
productive but also had more than $70 \%$ of the produced bulbs within the diameter range of 51-70 $\mathrm{mm}$. Conversely, the strains had a greater percentage of bulbs with a transverse diameter between 51 and $60 \mathrm{~mm}$.

Besides contributing to increase yield, a higher PB3 is preferred by the Brazilian consumer. It also means more market value since the price of Class 3 bulbs is up to $30 \%$ higher than that of Class 2 bulbs, guaranteeing greater profitability for the producer.

The equatorial diameter of the onion bulb is a genetic trait, with high heritability and genetic advancement (SHARMA et al. 2017; SINGH et al. 2017), which can be improved by efficient management of the crop, but there was no response of this characteristic to $\mathrm{K}$ fertilisation. The lack of response could be associated with the levels of $\mathrm{K}$ verified in the soil and irrigation water since these quantities were apparently sufficient to meet the requirement of the crop in terms of bulb size.

Differently from the results for PB2, PB3 and $\mathrm{PB} 4$, there was an effect of $\mathrm{K}$ fertilisation on PNMB, and the quadratic model fitted to the means (Figure 2).

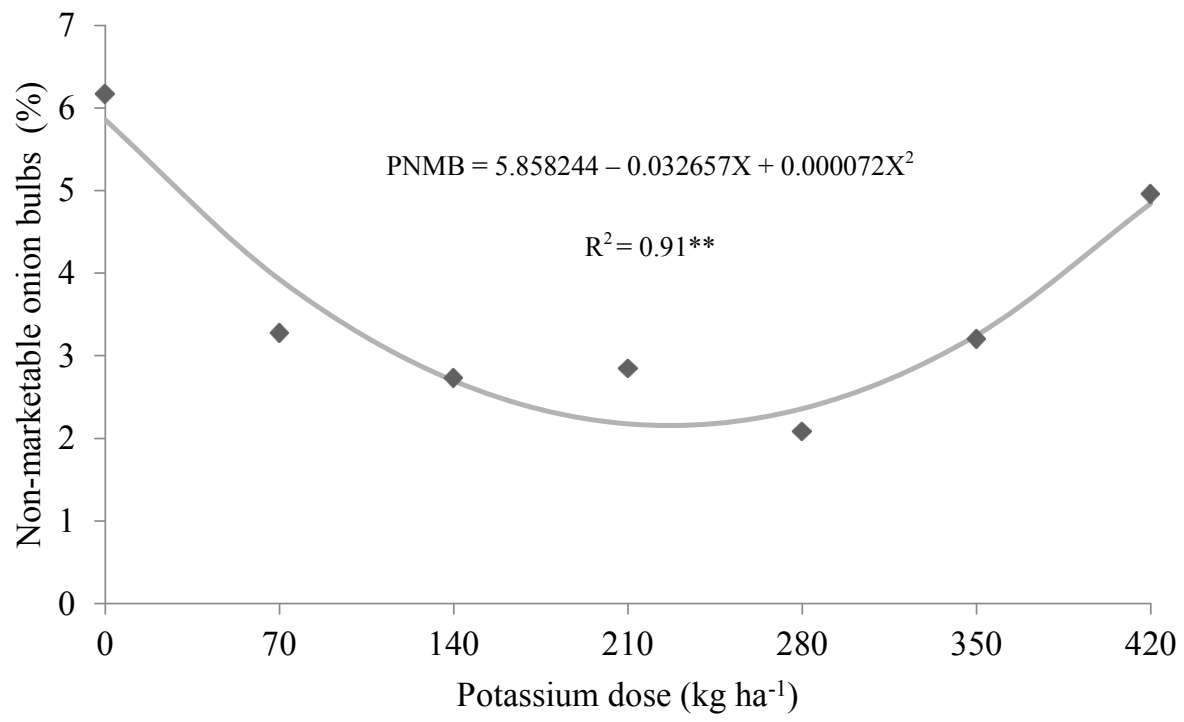

Figure 2. Percentage of non-marketable onion bulbs, as a function of potassium dose.

The minimum PNMB was $2.16 \%$ at the $\mathrm{K}_{2} \mathrm{O}$ dose of $226.8 \mathrm{~kg} \mathrm{ha}^{-1}$, which was very close to the dose responsible for maximum MY. An effect of K on the reduction of the NMY has also been observed by Resende and Costa (2008) and Resende et al.
(2009).

The SS differed statistically between the onion cultivars, with 'IPA 11' outperforming 'Rio das Antas' (Table 2).

Table 2. Means of soluble solids content (SS) and pungency (PUNG) of onion as a function of potassium dose and onion cultivar.

\begin{tabular}{ccc}
\hline Dose $\mathrm{K}_{2} \mathrm{O}\left(\mathrm{kg} \mathrm{ha}^{-1}\right)$ & $\begin{array}{c}\mathrm{SS} \\
\left({ }^{\mathrm{D}} \text { Brix }\right)\end{array}$ & $\begin{array}{c}\text { PUNG } \\
\left(\mu \mathrm{mol} \mathrm{g}^{-1}\right)\end{array}$ \\
\hline 0 & 9.03 & 3.98 \\
70 & 8.52 & 4.19 \\
140 & 8.73 & 4.09 \\
210 & 8.43 & 4.26 \\
280 & 8.60 & 4.67 \\
350 & 8.51 & 3.89 \\
420 & 8.74 & 4.33 \\
\hline Analysis of variance ${ }^{(1)}$ & $\mathrm{ns}$ & na \\
\hline Cultivars ${ }^{(2)}$ & $9.82 \mathrm{a}$ & $4.98 \mathrm{a}$ \\
IPA 11 & $7.48 \mathrm{~b}$ & $3.43 \mathrm{~b}$ \\
Rio das Antas & 8.65 & 4.20 \\
\hline Mean &
\end{tabular}

Rev. Caatinga, Mossoró, v. 32, n. 4, p. 889 - 896, out. - dez., 2019 
The SS values were within those found by Grangeiro et al. (2008), who evaluated 18 onion cultivars in Mossoró/RN (6.7 to $11.63^{\circ}$ Brix).

The SS mainly include sugars and organic acids (MELO et al. 2012), which are produced during photosynthesis. Since there is no photosynthesis in bulb tissues, the sugars produced in the shoots are translocated through the phloem to the bulb tissues, with $\mathrm{K}$ playing an important role. However, the SS content has a strong genetic influence (SHARMA et al. 2017; SINGH et al. 2017), meaning that the influence of the environment on this characteristic is limited to the genetic potential of the cultivar, which would explain the lack of influence of $\mathrm{K}$ fertilisation on this characteristic.

These results corroborate those verified by Syed et al. (2000), who evaluated the influence of $\mathrm{N}$ and $\mathrm{K}$ levels in the cultivar 'Swat 1', in a soil with $120 \mathrm{mg} \mathrm{dm}^{-3} \mathrm{~K}$, on the production of onion and its components, finding no influence of $\mathrm{K}$ fertilisation on the SS content, with values ranging from 6.88 to $9.06 \%$.

No mathematical model fitted to the mean contents of PUNG as a function of $\mathrm{K}$ dose. PUNG contents varied from 3.98 to $4.67 \mu \mathrm{mol} \mathrm{g}{ }^{-1}$. The cultivar 'IPA 11' had a $45.1 \%$ greater PUNG compared with 'Rio das Antas' (Table 2).

Onion PUNG is strongly correlated with the content of pyruvic acid (GALLINA et al. 2012). Although the genetic factor (cultivar) contributes to determining the onion chemical composition (KIMURA et al. 2014), the contents of the organic acids can be strongly influenced by the environment and agronomic practices (SEKARA et al. 2017).
The values observed were lower than those found by Santos et al. (2018), who evaluated the performance of onion cultivars as a function of plant spacing and observed that cultivar 'IPA 11' was more pungent than 'Rio das Antas', with PUNG values ranging from 6.06 to 6.92 and 4.85 to 5.67 $\mu \mathrm{mol} \mathrm{g}^{-1}$, respectively. Grangeiro et al. (2008), evaluating the qualitative characteristics of onion genotypes in Mossoró/RN, also recorded a higher PUNG value for cultivar 'IPA 11' (7.60 $\left.\mu \mathrm{mol} \mathrm{g} \mathrm{g}^{-1}\right)$ compared with that found in the present study.

$\mathrm{K}$ fertilisation positively influenced the PUNG of the onion cultivar 'Bellary Red' in a study conducted by Poornima et al. (2015), in which the $\mathrm{K}_{2} \mathrm{O}$ dose of $100 \mathrm{~kg} \mathrm{ha}^{-1}$ was responsible for maximum PUNG (2.44 $\left.\mu \mathrm{mol} \mathrm{g}^{-1}\right)$. Nabi et al. (2010), when working with the onion cultivar 'Swat 1', similarly, found a positive effect of $\mathrm{K}$ fertilisation on its PUNG, with maximum PUNG $(65 \%)$ at the $\mathrm{K}_{2} \mathrm{O}$ dose of $100 \mathrm{~kg} \mathrm{ha}^{-1}$, and minimum PUNG (35\%) at the $\mathrm{K}_{2} \mathrm{O}$ doses of 0 and $25 \mathrm{~kg} \mathrm{ha}^{-1}$.

No regression model fitted to the means of $\mathrm{TA}$ as a function of $\mathrm{K}$ dose, a result also noticed for the cultivar 'IPA 11', which showed a significant difference when the interaction of $\mathrm{K}$ doses was evaluated for each cultivar. The TA variation was 2.30 to $3.62 \mathrm{mEq} \mathrm{H}_{3} \mathrm{O}^{+} 100 \mathrm{~g}^{-1}$ for the cultivar 'IPA 11 ', and 2.47 to $2.96 \mathrm{mEq} \mathrm{H}_{3} \mathrm{O}^{+} 100 \mathrm{~g}^{-1}$ for 'Rio das Antas' (Table 3). These results corroborate those found by Poornima et al. (2015), who found positive effects of $\mathrm{K}$ fertilisation on the pyruvic acid contents of 'Bellary red' onion, with values varying from 1.47 to $2.44 \mu \mathrm{mol} \mathrm{g}{ }^{-1}$. The cultivar 'IPA 11' showed a lower TA than 'Rio das Antas' only at the $\mathrm{K}_{2} \mathrm{O}$ dose of $70 \mathrm{~kg} \mathrm{ha}^{-1}$ (Table 3).

Table 3. Means of titratable acidity (TA) and soluble solids/titratable acidity ratio (SS/TA), as a function of potassium dose and onion cultivar.

\begin{tabular}{|c|c|c|c|c|}
\hline \multirow{2}{*}{$\begin{array}{c}\text { Dose K } \\
\left(\mathrm{kg} \mathrm{ha}^{-1}\right)\end{array}$} & \multicolumn{2}{|c|}{$\mathrm{TA}\left(\mathrm{mEq} \mathrm{H} \mathrm{H}_{3} \mathrm{O}^{+} 100 \mathrm{~g}^{-1}\right)$} & \multicolumn{2}{|r|}{ SS/TA } \\
\hline & IPA $11^{(2)}$ & Rio das Antas & IPA 11 & Rio das Antas \\
\hline 0 & $3.62 \mathrm{a}$ & $2.59 \mathrm{~b}$ & $2.91 \mathrm{a}$ & $3.02 \mathrm{a}$ \\
\hline 70 & $2.30 \mathrm{~b}$ & $2.85 \mathrm{a}$ & $4.21 \mathrm{a}$ & $2.88 \mathrm{~b}$ \\
\hline 140 & $2.96 \mathrm{a}$ & $2.71 \mathrm{a}$ & $3.33 \mathrm{a}$ & $2.85 \mathrm{a}$ \\
\hline $\begin{array}{l}210 \\
280\end{array}$ & $\begin{array}{l}2.63 \mathrm{a} \\
2.96 \mathrm{a}\end{array}$ & $\begin{array}{l}2.47 \mathrm{a} \\
2.96 \mathrm{a}\end{array}$ & $\begin{array}{l}3.69 \mathrm{a} \\
3.40 \mathrm{a}\end{array}$ & $\begin{array}{l}2.97 \mathrm{~b} \\
2.47 \mathrm{~b}\end{array}$ \\
\hline 350 & $3.08 \mathrm{a}$ & $2.59 \mathrm{a}$ & $3.16 \mathrm{a}$ & $2.59 \mathrm{a}$ \\
\hline 420 & $3.20 \mathrm{a}$ & $2.47 \mathrm{~b}$ & $3.13 \mathrm{a}$ & $3.06 \mathrm{a}$ \\
\hline $\begin{array}{l}\text { Analysis of variance } \\
\text { regressão }^{(1)}\end{array}$ & na & na & na & na \\
\hline Mean $^{(3)}$ & $2.96 \mathrm{a}$ & $2.66 \mathrm{~b}$ & $3.41 \mathrm{a}$ & $2.84 \mathrm{~b}$ \\
\hline
\end{tabular}

${ }^{(1)}$ na $=$ nenhum modelo de regressão se ajustou aos dados. ${ }^{(2)}$ Médias seguidas pela mesma letra na coluna não diferem estatisticamente pelo Teste $\mathrm{F}$ a $5 \%$ de probabilidade. ${ }^{(3)}$ Médias seguidas pela mesma letra na linha não diferem estatisticamente pelo Teste Tukey a $5 \%$ de probabilidade.

No mathematical model fitted to the means of the SS/TA ratio either. A higher SS/TA ratio was determined in cultivar 'IPA 11 ' than 'Rio das Antas'. In relation to the $\mathrm{K}$ dose, the variation was from 2.91 to 4.21 and 2.47 to 3.06 for 'IPA 11 ' and 'Rio das Antas', respectively (Table 3 ).

Equating the first derivative of the equation of MY verified in Figure $1(105.62385-0.48936 X)$ to 
the equivalence ratio $(\mathrm{R} \$ 3.20 / \mathrm{R} \$ 1.25)$ led to the MEE of $210.6 \mathrm{~kg} \mathrm{ha}^{-1}$ of $\mathrm{K}_{2} \mathrm{O}$, which represents $97.5 \%$ of the dose of MTE and will result in $99.99 \%$ of the maximum marketable production.

There is no official recommendation for onion fertilisation in the state of Rio Grande do Norte. In Pernambuco, for soils with an intermediate $\mathrm{K}$ level, the recommended dose is $90 \mathrm{~kg} \mathrm{ha}^{-1}$ of $\mathrm{K}_{2} \mathrm{O}$ but applies to spacings of $0.15 \times 0.10$ or $0.10 \times 0.10 \mathrm{~m}$ (CAVALCANTE, 2008). Few Brazilian states have a recommendation for no-tillage. One of these is São Paulo, which, for soils with intermediate levels of $\mathrm{K}$, recommends $120 \mathrm{~kg} \mathrm{ha}^{-1}$ of $\mathrm{K}_{2} \mathrm{O}$ before planting and 40 to $160 \mathrm{~kg} \mathrm{ha}^{-1}$ of $\mathrm{K}_{2} \mathrm{O}$ as top-dressing (TRANI et al. 2014).

\section{CONCLUSIONS}

The cultivar 'Rio das Antas' was more productive and less pungent than 'IPA 11'. The MEE for marketable production was achieved with the $\mathrm{K}_{2} \mathrm{O}$ dose of $210.6 \mathrm{~kg} \mathrm{ha}^{-1}$. There was no influence of $\mathrm{K}$ fertilisation on onion quality and the classification of marketable bulbs.

\section{REFERENCES}

AFTAB, S. et al. Impact of potassium on the growth and yield contributing attributes of onion (Allium cepa L.). Asian Research Journal of Agriculture, v. 7, n. 3, p. 1-4, 2017.

ALLEN, R. G. et al. Crop evapotranspiration: guidelines for computing crop water requirements. 1 ed. Rome: FAO, 1998. 300 p. (Irrigation and drainage paper, 56).

BACKES, C. et al. Determination of growth and nutrient accumulation in Bella Vista onion. Revista Caatinga, v. 31, n. 1, p. 324-325, 2018.

BRASIL. Ministério da Agricultura, Abastecimento e Reforma Agrária. Portaria n. 529 de 18 ago. 1995. Diário Oficial da República Federativa do Brasil, Brasília, Seção 1, p. 13513, set. 1995.

BULL, L. T. et al. Variações no balanço catiônico do solo induzidas pela adubação potássica e efeitos na cultura do alho vernalizado. Scientia agrícola, v. 55, n. 3, p. 456-464. 1998.

CAVAlCANTE, F. J. A. Recomendações de adubação para o Estado de Pernambuco: $2^{\text {a }}$ aproximação. 3. ed. Recife, PE: IPA, 2008. 212 p.

CECÍLIO FILHO, A. B. et al. Produtividade e classificação de bulbos de cebola em função da fertilização nitrogenada e potássica, em semeadura direta. Científica, v. 38, n. 1/2, p. 14-22. 2010.

FAGERIA, V. D. Nutrient interactions in crop plants. Journal of Plant Nutrition, v. 24, n. 8, p. 1269-1290, 2001.

FARIA, M. V. et al. Desempenho agronômico e heterose de genótipos de cebola. Horticultura Brasileira, v. 30, n. 2, p. 220-225, 2012.

FERREIRA, D. F. Sisvar: A computer statistical analysis system. Ciência e Agrotecnologia, v. 35, n. 6, p. 1039-1042, 2011.

GALLINA, P. M. et al. Changes in the pyruvic acid contente correlates with phenotype traits in onion clones. Australina Journal of Crop Science, v. 6, n. 1, p. 36-40, 2012.

GRANGEIRO, L. C. et al. Características qualitativas de genótipos de cebola. Revista Ciência e Agrotecnologia, v. 32, n. 4, p. 1087-1091, 2008.

KAUR, A. et al. Response of onion to applied potassium at farmer's scale field. International Journal of Current Microbiology and Applied Sciences, v. 6, n. 7, p. 2491-2496, 2017.

KIMURA, Y. et al. Cultivar and regional differences in the metabolite composition of onion (Allium cepa). Scientia Horticulturae, v. 168, n. 1, p. 1-8, 2014.

LUCENNA, R. R. M. et al. Crescimento e acúmulo de macronutrientes em melancia 'Quetzale' cultivada sob diferentes níveis de salinidade da água de irrigação. Revista Caatinga, v. 24, n. 1, p. 34-42, 2011.

MARROCOS, S. T. P. et al. Potassium fertilization for optmization of onion production. Revista Caatinga, v. 31, n. 2, p. 379-384, 2018.

MAATHUIS, J. M. F. Physiological functions of mineral macronutrients. Current Opinion in Plant Biology, v. 12, n. 3, p. 250-258, 2009.

MELO, C. O. et al. Alterações físicas e químicas em cebolas armazenadas sob refrigeração. Ciência Rural, v. 42, n. 11, p. 2078-2084, 2012.

MORAES, C. C. et al. Fenologia e acumulação de nutrientes por cebola de dias curto em semeadura direta. Revista de Ciências Agrárias, v. 39, n. 2, p. 281-290, 2016.

NABI, G. et al. Influence of different levels of potash on the quantity, quality and storage life of onion bulbs. Pakistan Journal of Botany, v. 42, n. 
3, p. 2151-2163, 2010 .

PAVLOVIC, N. et al. Mode of inheritance and ammi analysis of onion (Allium cepa L.) bulb traits. Genetika, v. 49, n. 2, p. 729-742, 2017.

POORNIMA, K. S. et al. Effect of potassium and sulphur on quality parameters of onion and chilli intercrops in a vertisol. Advance Research Journal of Crop Improvement, v. 6, n. 2, p. 166-169, 2015.

POORNIMA, K. S. et al. Effect of potassium and sulphur on yield e yield attributes of onion and chilli intercrops in a vertisol. Asian Journal of Soil Science, v. 11, n. 1, p. 58-61, 2016.

RÊGO, L. G. S. et al. Pedogenesis and soil classification of an experimental farm in Mossoró, state of Rio Grande do Norte, Brazil. Revista Caatinga, v. 29, n. 4, p. 1036-1042, 2016.

RESENDE, G. M.; COSTA, N. D. Épocas de plantio e doses de nitrogênio e potássio na produtividade e armazenamento da cebola. Pesquisa Agropecuária Brasileira, v. 43, n. 2, p. 221-226, 2008.

RESENDE, G. M. et al. Rendimento e conservação pós-colheita de bulbos de cebola com doses de nitrogênio e potássio. Horticultura Brasileira, v. 27, n. 2, p. 139-143, 2009.

RESENDE, G. M. et al. Doses de nitrogênio na produtividade e classificação de bulbos de cultivares de cebola. Revista Brasileira de Agricultura Irrigada, v. 10, n. 3, p. 605-613. 2016.

SANTOS, J. P. et al. Performance of onion cultivars as a function of spacing between plants. Revista Brasileira de Engenharia Agrícola e Ambiental, v. 22, n. 3, p. 212-217. 2018.

SAUD, S. et al. Effect of potash levels and row spacings on onion yield. Journal of Biology Agriculture Healthcare, v. 3, n. 16, p. 118-127. 2013.

SEKARA, A. et al. Interactions among genotype, environment and agronomic practices on production and quality of storage onion (Allium cepa L.) - A review. Horticultural Science, v. 44, n. 1, p. 21-42. 2017.

SHARMA, P. K. et al. Genetic variability, heritability and genetic advance in onion (Allium cepa var. Cepa L.), International Journal of Pure \& Applied Bioscience, v. 5, n. 6, p. 740-743, 2017.
SINGH, P. et al. Genetic variability assessment in onion (Allium cepa L.) genotypes. International Journal of Chemical Studies, v. 5, n. 5, p. 145-149, 2017.

SYED, N. et al. Onion yield and yield componentes af function of the levels of nitrogen and potassium application. Pakistan Journal of Biological Sciences, v. 3, n. 12, p. 2069-2071, 2000.

TAIZ, L. et al. Fisiologia e desenvolvimento vegetal. 6. ed. Porto Alegre, RS: ARTMED, 2017. $888 \mathrm{p}$

TRANI, P. E. et al. Calagem e adubação da cebola (Allium cepa L.). Campinas: Instituto Agronômico. 2014. 35 p.

VIDIGAL, S. M. et al. Crescimento e absorção de nutrientes pela planta cebola cultivada no verão por semeadura direta e por transplantio de mudas. Bioscience Journal, v. 26, n. 1, p. 59-70, 2010. 